\title{
5. Education and philanthropy in the Middle East and North Africa
}

\section{Natasha Y. Ridge, Susan Kippels and Elizabeth R. Bruce}

\section{INTRODUCTION AND BACKGROUND TO PHILANTHROPIC GIVING IN THE MIDDLE EAST AND NORTH AFRICA}

In North America and Europe, philanthropic foundations established by individuals, families and corporations have been operating in the education sector for over one hundred years (Arnove, 1984; Berman, 1983; Eikenberry \& Nickel, 2006; Zunz, 2014). Globally, however, the last two decades have seen a significant increase in the level of involvement of philanthropic organisations in the education sector in most regions of the world, including the Middle East and North Africa (MENA) (Srivastava \& Oh, 2010; Zunz, 2014). The growth in giving in the MENA region appears to have been driven by two key factors: first, a strong religious or cultural imperative to give back (Farouky, 2016; Ibrahim, 2008) and second, growing levels of personal and state wealth across the MENA region that have created a greater capacity for philanthropic giving (Knight \& Ribeiro, 2017).

While there has been some research on philanthropic activities in the MENA region, there is a lack of recent, reliable and comprehensive data on specific philanthropic activities, and no research has examined philanthropic efforts focused on the education sector. This chapter seeks to address this gap and explore the trends in giving and the opportunities for philanthropic organisations in the MENA region. The data used in this chapter comes from a study that examined 65 foundations operating in the education sector in 11 MENA countries. The countries included are Bahrain, Egypt, Israel, Jordan, Kuwait, Lebanon, Oman, Palestine, Qatar, Saudi Arabia and the United Arab Emirates (UAE). For simplicity, the included philanthropic entities are referred to as 'foundations' or 'philanthropic organisations' throughout the chapter. 
In summary, we find that while there is growing philanthropic activity in the education sector, much of the giving goes towards similar populations (those in higher education, secondary and primary school) and is given largely for programmatic work or scholarships. Additionally, we find that there is very little philanthropic funding for research on education or for programmes directed at the early childhood sector or for teacher development. Thus, philanthropic organisations working in the region could be missing unique opportunities to contribute something original to the MENA education sector or to assist populations that regional governments have neglected. Finally, we find that the funding model of the philanthropic organisation plays a significant role in the priorities of the organisation.

In this chapter, we first explore the definition of a philanthropic organisation. Next, we analyse the funding types of philanthropic organisations in the region, followed by the key areas of support and beneficiaries. We then use data from our interviews to explore institutional challenges and conclude with a discussion of current trends in MENA philanthropy and suggestions for future research.

\section{CONCEPTUALISING PHILANTHROPIC ORGANISATIONS}

As the number of organisations around the world that identify as being philanthropic has grown (Eikenberry \& Nickel, 2009; Hudson Institute, 2015; Zunz, 2014), a discussion has arisen both in academia and in the field itself about what exactly constitutes a philanthropic entity. Frequently, there is confusion around the difference between a non-profit or nongovernmental organisation and a philanthropic organisation. Additional confusion also arises when we consider public charities, such as the Red Cross and Red Crescent, which solicit donations from the general public. Based on our own experience in the sector, many groups ostensibly identify as philanthropic organisations but are often reliant on multiple grants or donations from other entities rather than having their own endowment or independent revenue stream. As such they are essentially acting as intermediaries and are beholden to third parties in terms of setting their priorities and choosing what they do. In addition, the lack of a stable revenue stream means that these organisations have to continually expend efforts to fundraise thus taking time and resources away from the core business. ${ }^{1}$

1 Fundraising distracts from the core mission of organisations and requires additional resources. A study by Hager, Pollak and Rooney (2001) found that the distribution of 
For the purposes of this chapter, we constructed a definition that is consistent with the United States' tax definition of a private foundation (Internal Revenue Service, 2017) and with those used in previous research. ${ }^{2}$ We therefore define a philanthropic entity as one which:

a) is financially independent and receives the majority of its funding (over 50 per cent) from a single source (through an endowment or otherwise); ${ }^{3}$

b) has no shareholders;

c) disperses funds (through grants, scholarships or programmes for educational, cultural, religious, social or other public development endeavours);

d) can be operational (running its own programmes) or non-operational (supporting other entities to carry out the work);

e) does not receive or solicit funds from the general public (not a public charity); and

f) is not an official government agency (e.g., the Department for International Development or the United States Agency for International Development).

\section{PHILANTHROPY AND EDUCATION IN THE MENA REGION}

This chapter is based on data taken from 65 philanthropic organisations operating in 11 countries. In order to be included, organisations had to be in operation between December 2017 and January 2018, originate in the region and have some kind of online presence. After this, we applied our definition of a philanthropic organisation and using the information available online, we then eliminated those which did not meet our definition. ${ }^{4}$

fundraising expenses as a per cent of the contributions sector ranged from an average of seven per cent at the lowest quartile up to 58 per cent at the highest quartile for education non-profit organisations. The BBB Wise Giving Alliance Standards for Charity Accountability (2003) recommends that no more than 35 per cent of contributions be spent on fundraising.

2 We reviewed definitions from the Council on Foundations (n.d.), Marten and Witte (2008), Srivastava and Oh (2010), and the Worldwide Initiatives for Grantmaker Support (2018). The definition which is used in our study draws heavily from a definition used in a recent study by Johnson and Rahim (2018, p. 20) and also borrows from the Association of Charitable Foundations (n.d.), Cullinane (2013) and the Foundation Center (n.d.).

3 To the best of the authors' knowledge in the region.

4 While some organisations identified in the first stage were no longer operational, most of the others were charities (i.e., not philanthropic organisations because they failed to meet criteria). 
We were left with 65 philanthropic entities from 11 countries. ${ }^{5}$ Of these 11 countries, six are members of the Gulf Cooperation Council (GCC): ${ }^{6}$ Bahrain, Kuwait, Oman, Qatar, Saudi Arabia and the UAE, while the remaining five are non-GCC countries: Egypt, Israel, Jordan, Lebanon and Palestine.

Following the identification of these foundations, data from websites, annual reports and various other online sources were collected. After aggregating this information, all 65 foundations were contacted for interviews. Of those contacted, 20 organisations from 10 countries participated in the interviews. ${ }^{7}$

Both sets of data were analysed in order to provide an overview of philanthropic activity in the MENA education sector, as well as to identity oversaturated or neglected areas. In this chapter, we will examine the data related to funding models and patterns in funding with regard to activities, beneficiaries and challenges and opportunities.

\section{Funding Typology}

The first area that we examined when looking at philanthropic organisations in the MENA region was their funding model or, more precisely, where the majority of their funding originated. Three distinct categories emerged: (1) state-funded, (2) private individual/family funded and (3) business/corporation funded. Using the information available, we then formed a more detailed typology of philanthropic funding, as detailed in Table 5.1 .

Using this typology, we were then able to identify some interesting differences depending on the funding model. In particular, as can be seen in Figure 5.1, the GCC has a smaller percentage of business/corporation philanthropic organisations than the non-GCC countries. In contrast, the majority of philanthropic organisations in non-GCC countries tend to be private or family foundations, with only around a quarter being state-funded.

Funding models are of interest as they speak to the size or activity of civil society in a region. They may also reflect the commitment of a country's citizens to developing their own country and provide some insight into the role of the private sector in education. We also find that

\footnotetext{
5 For a complete list of the foundations included, please contact the chapter authors.

6 The GCC, according to its Charter, was established in 1981 to strengthen collaboration and ties among its members across various sectors.

7 Multiple foundations declined to speak about their work. We conducted interviews with foundations in each of the 11 countries included in this study, with the exception of those in Lebanon. The authors of this study work for the Sheikh Saud bin Saqr Al Qasimi Foundation for Policy Research, counted among the organisations interviewed.
} 
Table 5.1 Typologies of philanthropic organisations for education in the MENA region

\begin{tabular}{|c|c|}
\hline Typology & Description \\
\hline $\begin{array}{l}\text { State } \\
\text { (Royalty \&/or } \\
\text { government- } \\
\text { including } \\
\text { decrees) }\end{array}$ & $\begin{array}{l}\text { - A president, parliament or emir may issue a decree to } \\
\text { establish a foundation (Khallaf, 2008). } \\
\text { - Funding comes from the state or the royal family. } \\
\text { - Foundations started by governments have the ability to exert } \\
\text { power beyond that possible with assistance programmes } \\
\text { traditionally administered (Brenner, 2012; Ridge \& Kippels, } \\
\text { 2017). } \\
\text { Example: King Faisal Foundation (Saudi Arabia) }\end{array}$ \\
\hline $\begin{array}{l}\text { Private } \\
\text { individual/ } \\
\text { family }\end{array}$ & $\begin{array}{l}\text { A philanthropic organisation is established on someone's } \\
\text { own behalf, on their entire family's behalf or on another } \\
\text { family member's behalf and funded by the individual or } \\
\text { family. } \\
\text { Example: Abdulla Al Ghurair Foundation for Education (UAE) }\end{array}$ \\
\hline $\begin{array}{l}\text { Business/ } \\
\text { corporation }\end{array}$ & $\begin{array}{l}\text { This typically starts as a business department, potentially } \\
\text { evolving into a separate entity still associated with its } \\
\text { founding company and continuing to be funded via } \\
\text { company profits (Ibrahim, 2008). } \\
\text { Corporate social responsibility programmes targeting } \\
\text { education are common in many company portfolios (see } \\
\text { Moeller, } 2014 \text { ). } \\
\text { Example: EFG-Hermes Foundation (Egypt) }\end{array}$ \\
\hline
\end{tabular}

the funding model influences the priorities of philanthropic organisations and their beneficiaries, while also playing a role in broader institutional challenges, which we examine in the next section.

\section{Areas of Support: Programmes, Scholarships, Infrastructure/Tangibles and Education Research}

Philanthropic organisations operating in the MENA region provide support to the education sector in a variety of forms, which we have grouped into four overarching categories: (1) programmatic offerings, (2) scholarships, (3) infrastructure/tangibles and (4) education research. ${ }^{8}$ The two most common areas of support provided by foundations were programmatic

8 Our understanding of foundations' involvement in these activities is based on our review of public information provided by the foundations themselves, not audits or interviews with the foundations, and thus may not capture all activities of foundations. 


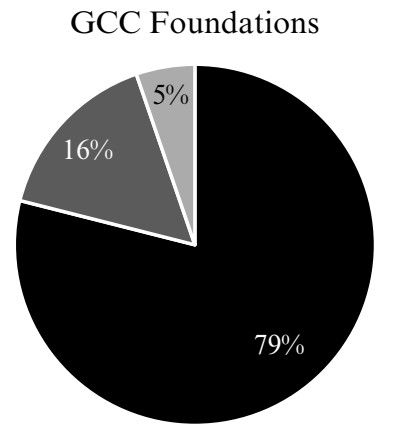

- State

- Private individuals/families

- Businesses/corporations
Non-GCC Foundations

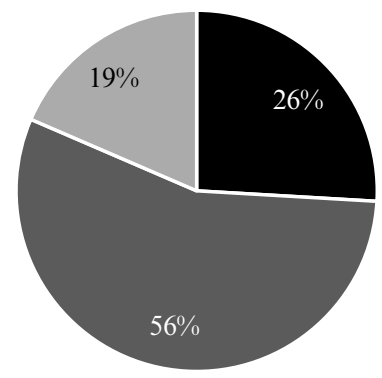

- State

- Private individuals/families

- Businesses/corporations

Notes:

GCC countries are Bahrain, Kuwait, Oman, Qatar, Saudi Arabia and the UAE (38 foundations). Non-GCC countries are Egypt, Israel, Jordan, Lebanon and Palestine (27 foundations).

The total percentage for non-GCC foundations adds up to $101 \%$ due to rounding.

\section{Figure 5.1 Funding of foundations in the MENA region: state, private individuals/families or businesses/corporations in GCC countries versus non-GCC countries, by percentage (\%)}

work and scholarships, as shown in Figure 5.2. We found that 89 per cent of foundations were engaged in programmatic work, which we defined as educational activities or events held regularly, rather than a one-off initiative or event. Examples of programmatic work include student courses, workshops for educators, vocational and career/entrepreneurship training for youth ${ }^{9}$ and classes for parents to support their children's learning. The second most common type of support was the provision of scholarships, with 66 per cent of philanthropic organisations providing scholarships of some sort. Of these scholarships, the majority were for higher education ( 95 per cent) ${ }^{10}$

The third most common area of support shown in Figure 5.2 was

9 Vocational training is broadly defined as providing skills for a particular job function or trade. Career/entrepreneurship support includes executive education, leadership education and social entrepreneurship, to name a few. It also includes training for specific employment positions. For example, within career/entrepreneurship, the Sawiris Foundation for Social Development (Egypt) approaches training by first finding vacant jobs and then training individuals specifically for those jobs, following a commitment to hire by employers (Sawiris Foundation, 2018).

10 This includes support for educators to continue their education. 


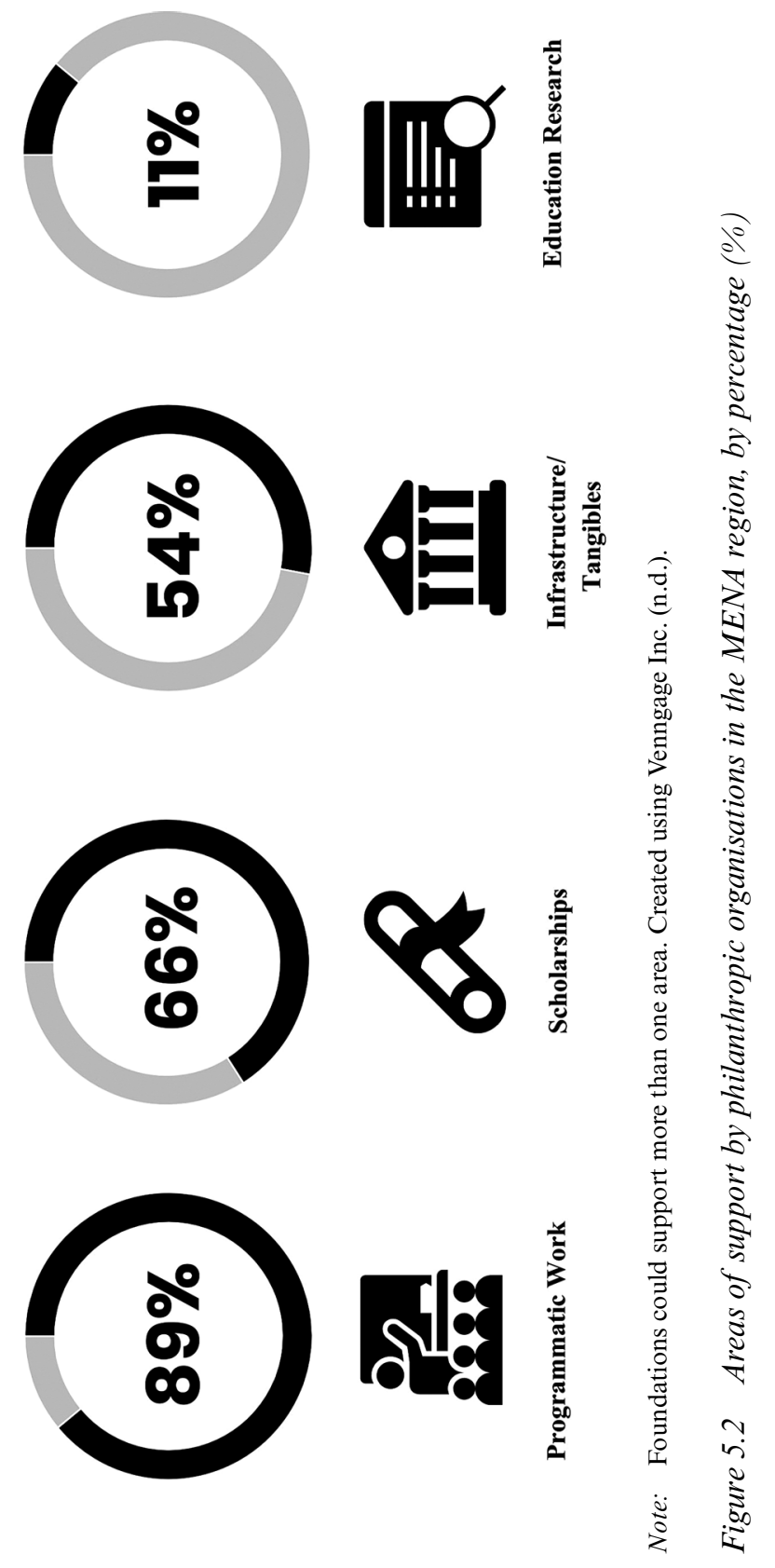


infrastructure/tangibles, with 54 per cent of foundations supporting this area. The infrastructure/tangibles category refers to the provision of educational facilities or material items. When looking more closely at the types of projects, we found that the majority of infrastructure projects focused on building schools (49 per cent), renovating school facilities (37 per cent) or providing educational equipment (29 per cent). In addition, less common infrastructure/tangibles projects included the construction of vocational training centres, museums and cultural centres.

Finally, and significantly less than any other area, there was support for research. Across the MENA region, there is a dearth of publicly available research on education. This is reflected in only 11 per cent of MENA philanthropic organisations supporting research in some way. In order to be counted as supporting research, foundations had to either conduct their own research or fund research related to education and share it as some kind of publication on their website. ${ }^{11}$ Following the determination of the number of organisations conducting research, we also identified and analysed the 109 publications that were present on their websites. ${ }^{12}$ From this, we were able to identify the most common research topics. We found that the most popular were papers on curriculum and assessment (28 per cent), followed by education systems (26 per cent).

When we cross-referenced the areas of support with the funding type (see Figure 5.3) we were able to reveal some interesting trends in the ways that different types of philanthropic organisations work. In terms of commonalities, we can see that across all funding models, programmatic work was the most supported area by all types of foundations. In terms of areas of divergence though, business/corporation funded philanthropic organisations preferred to fund infrastructure projects over scholarships and gave nothing to research. This is in contrast to state-funded foundations, which preferred to fund scholarships over infrastructure and prioritised research more. Private foundations also preferred scholarships to infrastructure and allocated some funding to research. Thus, it appears that in terms of the ongoing impact on education, through a combination of building human capacity and a knowledge repository on education, private and state-funded foundations may be more active and forward-looking than business/corporation foundations.

11 While the Israel Science Foundation (ISF) conducts research in primary and secondary schools connected to its Center for Excellence in Meaningful Learning, publications related to this research were not found on its website. Thus, the ISF was excluded from education research in this analysis.

12 A total of 110 publications were found on the foundations' websites in February/ March 2018. One from A. M. Qattan Foundation, a journal series entitled Rua' Tarbawiyya covering a variety of education research topics, was not included in this tabulation. 


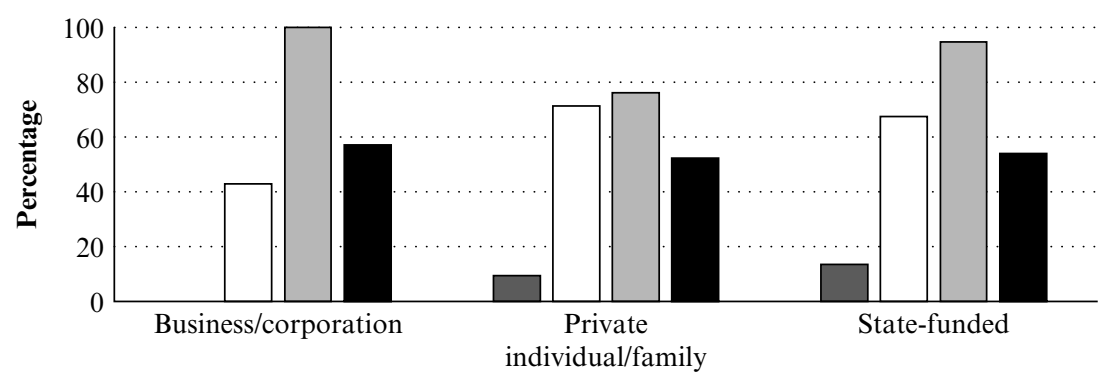

Type of foundation

$\square$ Research $\square$ Scholarships $\square$ Programmatic Areas $\square$ Infrastructure \& Tangibles

Note: Foundations could have more than one area of focus.

Figure 5.3 Areas of support for state, private individuallfamily and business/corporation foundations, by percentage (\%)

\section{Beneficiaries}

We next examined the programmatic work of philanthropic organisations in terms of their targeted beneficiaries. We found that 84 per cent of foundations targeted students, 64 per cent targeted youth and adults not involved in the education sector and only 41 per cent of foundations targeted educators for programmatic work (see Figure 5.4). In each of the non-GCC countries, programmes for educators were offered by at least one foundation. However, in three GCC countries, Bahrain, Kuwait and Oman, there were no educator programmes offered by philanthropic organisations. In the UAE, five foundations supported programmes for educators; however, the majority of these programmes were not targeting educators working in country.

In regard to the geographic location of beneficiaries, we found that foundations from GCC countries were more likely to provide support for people and organisations outside of their home countries. Sixty-three per cent of GCC foundations did international work versus 22 per cent of non-GCC foundations. This means that philanthropic organisations from non-GCC countries tended to focus their work on domestic issues, as opposed to GCC countries. This raises questions around the different purposes of philanthropy in the two regions. The difference could be related to wealth, as the GCC countries have greater financial resources than many of the non-GCC countries which enable them to do work outside of their home countries. However, it could also point to the differing priorities of 


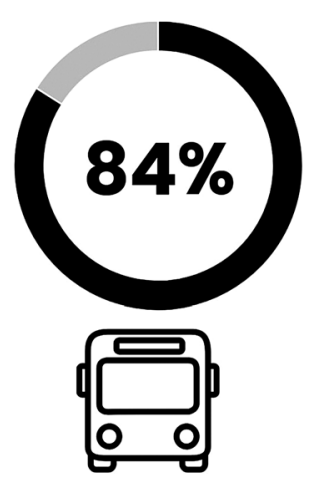

Students

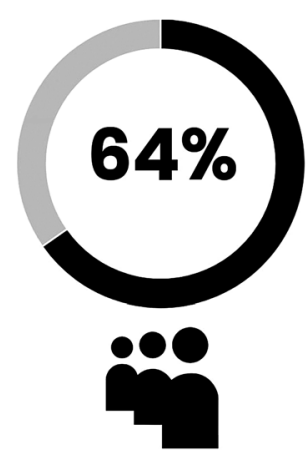

Youth \& Adults (not in the

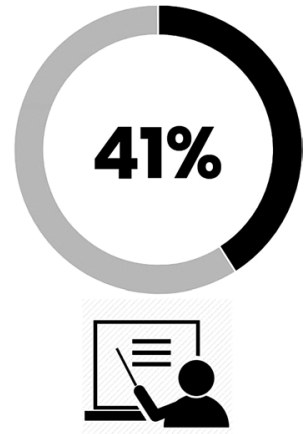

Educators Education Sector)

Note: Foundations could be targeting more than one group of beneficiaries. Created using Venngage Inc. (n.d.).

Figure 5.4 Beneficiaries of philanthropic organisations in the MENA region, by percentage (\%)

state-funded philanthropy, which is more common in the GCC region, in comparison to those of private and corporate philanthropy, which are more common in the non-GCC countries.

We also analysed the beneficiaries by level of education and found that the least targeted beneficiaries across the MENA countries were those in the pre-primary sector, ${ }^{13}$ with only 29 per cent of foundations supporting this group. ${ }^{14}$ However, there was a relatively even distribution of support across primary (63 per cent), secondary ( 75 per cent), higher education ( 75 per cent) and adult ${ }^{15}$ (80 per cent) populations.

Finally, in order to better understand foundation beneficiaries, we cross-referenced the funding type with programme beneficiaries to identify commonalities and differences, shown in Figure 5.5. We found that the most targeted beneficiaries for state-funded foundations and private individual/family foundations were students, while business/corporation foundations were more likely to focus on youth and adults not involved in the education sector. Eighty-six per cent of state-funded foundations and 67 per cent of individual/family foundations support

\footnotetext{
13 Pre-primary includes newborn to 5 years old.

14 These percentages were calculated based on the number of target populations being reached by foundations. A foundation could be serving more than one population.

15 Includes educators.
} 


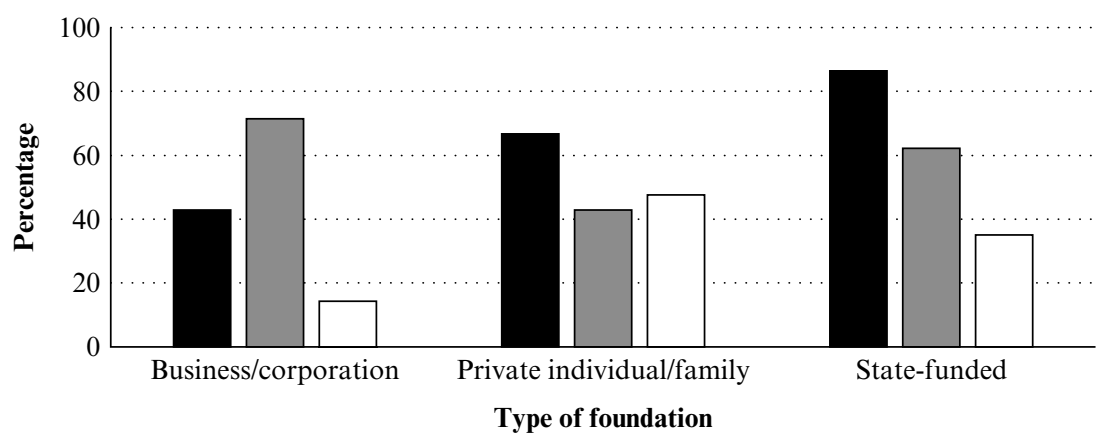

Students $\square$ Youth \& adults (not involved in the education sector) $\square$ Educators

Note: Foundations could support more than one type of beneficiary.

Figure 5.5 Beneficiaries of state, private individual/family and business/ corporation foundations' programmatic support, by percentage $(\%)$

programmatic activities for students, in contrast to only 43 per cent of business/corporation foundations. Seventy-one per cent of business/ corporation foundations support youth and adults not involved in the education sector, compared to 62 per cent of state-funded foundations and 43 per cent of individual/family foundations. The high percentage of business/corporation foundations targeting youth and adults outside of the formal education sector is possibly explained by the funding's roots in the commercial world (for example, multiple business/corporation foundations fund programmes developing entrepreneurship skills). Also of note is that approximately half of private individual/family foundations and over one third of state-funded foundations support educators, in contrast to only 14 per cent of business/corporation foundations.

\section{INSTITUTIONAL CHALLENGES FOR THE MENA PHILANTHROPIC SECTOR}

For the next stage of the study, interviews were analysed. In terms of the interview participation rate, only 14 per cent of all business/corporation foundations (1) agreed to be interviewed, in contrast to 27 per cent of individual/family foundations (6) and 35 per cent of state-funded foundations (13). Even after agreeing to be interviewed, however, many foundations 
Table 5.2 Institutional challenges identified by foundations in interviews

\begin{tabular}{lccc}
\hline & $\begin{array}{c}\text { Funding } \\
(\%)\end{array}$ & $\begin{array}{c}\text { Staffing } \\
(\%)\end{array}$ & $\begin{array}{c}\text { Government } \\
\text { Relationships/ } \\
\text { Regulations } \\
(\%)\end{array}$ \\
\hline Private individual/family & 50 & 17 & 17 \\
State-funded & 54 & 38 & 23 \\
\hline Overall & $\mathbf{5 0}$ & $\mathbf{3 0}$ & $\mathbf{2 0}$ \\
\hline
\end{tabular}

were reluctant to provide detailed responses, not only relating to challenges but even more generally.

During interviews, foundation representatives were asked about whether they faced any institutional challenges and, if so, what those were. The single business/corporation foundation interviewee did not identify any challenges that their foundation was facing. As such, the challenges that are discussed in this section are based on responses provided by private individual/family and state-funded foundations. Interestingly, the three main challenges identified were funding, governmental relationships/ regulations and staffing, which can be seen in Table 5.2. Two state-funded foundations also mentioned that they faced some challenges related to monitoring and evaluation (M\&E).

The most frequent challenge raised in interviews by both individual/ family and state-funded foundations was related to funding, with approximately half of all interviewees citing this as an issue, and almost an equal breakdown between each foundation type (50 per cent and 54 per cent, respectively). Even if foundations had at one time received the majority of their funding from a private individual/family or the state, it was common for them to financially partner with others and/or seek external funds. One family foundation based outside the GCC explained that for them, 'The most significant institutional challenges the foundation faces are fundraising and the difficult political and living conditions' (Interview 6, translated from Arabic, 2018). Similarly, state-funded foundations also discussed how securing funding was a core challenge. One stated, 'We do not have a large endowment and rely on fundraising to meet our on-going needs' (Interview 9, 2018). Another state-funded philanthropic organisation in the GCC explained, 'Projects are based off funding [even though the foundation was started initially with a large endowment from royalty]. . so we have to go to businessmen, investors, etc. It's hard to do.. . . It does detract from our main work' (Interview 2, 2018). The challenge of funding was surprising, as according to our definition of a philanthropic organisation a primary 
characteristic is that they are financially independent and essentially not required to be engaged in fundraising, which is more typical for non-profits. It further raises concerns about how a shortage of financial resources may not only detract from foundations' core missions and activities but also about how many truly philanthropic organisations there are in the region.

The second most common institutional challenge was identified by 30 per cent of foundations and related to staffing. In regard to staffing, there were differences between the degree to which private individual/family and state-funded foundations perceived it to be an issue. While only 17 per cent of family foundations noted staffing as a challenge, 38 per cent of state-funded foundations did. Staffing issues mentioned included difficulty finding skilled talent, large amounts of work for small teams and the transient nature of workers in the philanthropic sector. One non-GCC state-funded foundation provided an example of issues related to securing skilled talent, specifically in the evaluation sector: 'Some of the challenges we have faced include (1) a shortage of skilled evaluators in the region, (2) a shortage of quality data collection suppliers. .' (Interview 9, 2018). A GCC state-funded philanthropic organisation discussed the shortage of staff saying, 'One of the big challenge[s] we face is the lack of human resources. We're a small department, although we're doing projects [worth millions]' (Interview 13, 2018). Another GCC state-funded foundation also discussed the issue of staff 'roaming' from organisation to organisation in the philanthropic sector and that it can hinder institutional development (Interview 12, translated from Arabic, 2018).

Third, challenges relating to government relationships and processes/ regulations were expressed in 20 per cent of interviews, roughly equally between family and state-funded foundations ( 17 per cent and 23 per cent, respectively). In terms of the specific challenges, one GCC state-funded foundation shared that 'unclear/different priorities within the same governmental entity [and] delay[s] in government processes' negatively impact its work (Interview 14, 2018). Another GCC state-funded foundation stated that 'regulations and code[s] of practice that prevent the receipt of funds from outside the Kingdom of Saudi Arabia' act as a barrier for their work (Interview 12, 2018). Concern around government regulations is one factor that existing research on the topic of philanthropy in the MENA region often discusses. The research by Farouky (2016), the Hudson Institute (2015) and Johnson and Rahim (2018) has found that restrictions or ambiguity around processes for establishing philanthropic institutions in the region may be hindering activities, including in the education sector. Interestingly, there were approximately equal numbers of foundations that noted that government relationships made their work easier rather than more challenging. However, these organisations indicated that they rely on 
personal networks, such as close connections between their founder and high-ranking politicians or rulers, which enable them to bypass existing governmental structures and regulations that may hinder those foundations without such a network.

There were also two GCC state-funded foundations that mentioned $\mathrm{M} \& \mathrm{E}$ as a challenge. Specifically, one of these mentioned the 'weakness of the philanthropic/non-profit sector and the non-measurement of the impact of programmes and projects, which, in turn, makes it difficult to accurately measure the impact of grants given by foundations to beneficiary groups' (Interview 12, 2018), while the other believed that there is 'a lack of awareness about the use and value of evaluation evidence for programming or policy' (Interview 9, 2018). This lack of awareness of the importance of $M \& E$ in general is reflected by the fact that when foundations were asked, for this study, if they engaged in M\&E in their work, 50 per cent of family foundations and 40 per cent of state-funded foundations said they did not. So it is not entirely surprising that they then did not identify it as a challenge.

\section{DISCUSSION OF MENA PHILANTHROPY IN THE EDUCATION SECTOR}

The MENA philanthropic sector is still very much in its early stages. This is evidenced by a great deal of ambiguity over exactly what constitutes a philanthropic organisation and the great variety of organisations working in the region. For those working in the education sector, our research revealed a number of interesting and sometimes contradictory issues. First, there appear to be some serious challenges related to the sustainability of regional philanthropic organisations. Second, MENA philanthropic organisations, depending on their funding type, are clustered around particular populations and particular programmes leaving some areas of the education sector neglected. Finally, little value and support is given to research, particularly by corporate foundations and to a lesser degree by family foundations, and M\&E. Each of these is discussed below.

In order for MENA philanthropic organisations to become long-term strategic partners and actors in the education sector they first need to be sustainable. However, our research revealed that many organisations lack the secure and steady income streams that would enable them to focus on their core missions. As a result, they are forced to fundraise from various private sector and other government organisations. This is problematic on a number of levels. First, the regional private sector is currently experiencing a downturn and thus has limited resources available for charitable 
endeavours and will want to be strategic about how it allocates the funding it has. Second, the government sector can directly fund its own educational activities and the question will be rightly raised about why it should give funding to private philanthropic efforts. As such, unless regional philanthropic organisations are supplied with adequate, long-term funding that will allow them to at least undertake their core activities, it seems that many organisations may not be around into the future.

In addition, there also needs to be greater attention given to addressing the issues of staffing, as being able to attract and retain qualified personnel is also essential to sustainability. There are, to the best of our knowledge, few university programmes offering courses on the philanthropic sector in the Middle East. This seems to be a major gap in higher education offerings if the sector is to gain regional buy-in and nurture regional talent.

The final point related to sustainability is that government regulations seem to be in need of greater examination in order to learn if they are indeed conducive to incentivising wealthy individuals or companies to establish philanthropic organisations. If there are too many barriers or not enough incentives, then it may well be that fewer and fewer people or organisations decide to enter the philanthropic space. In recent years in the Gulf, there has been a significant tightening of the laws around establishing charitable organisations in general, and, anecdotally, this has caused a number simply to close up shop. While there indeed might be good reasons to have greater regulation of the sector, this could be done in consultation with existing actors in order to enable greater levels of philanthropy.

As well as issues relating to sustainability, there are also issues that relate to an overconcentration on particular programmes and populations. While it is understandable that certain types of philanthropic organisations prefer to work in certain areas with certain people, this may have led to a neglect of some critically important education stakeholders, such as educators and pre-primary students, and sub-sectors within education, including M\&E and research. Educators, whether through scholarships and/or programming, could benefit from increased attention from philanthropic organisations operating in education. Scholarship support for the professional development of educators is especially lacking in the GCC countries (except in Qatar and the UAE), as well as in Lebanon and Palestine. By providing only limited support to these individuals, philanthropic organisations are missing an opportunity to support building long-term education capacity. Teachers should be a natural focus for supporting education programming, as Rice (2003) has found teachers to be the most important school-related factor influencing student achievement.

Regional philanthropic organisations could also benefit from giving greater attention to pre-primary students. Currently, students from Grade 1 
through higher education, as well as adults, receive significantly more support from foundations than pre-primary students. The large amount of support for older children and youth is expected as a youth bulge exists across the MENA region, and global trends show large amounts of money earmarked for projects targeting youth (Farouky, 2016; Ridge \& Kippels, 2017). However, programmes by MENA foundations for pre-primary age individuals are notably scarce, despite research by Cunha and Heckman (2007) and Schütz, Ursprung and Woessmann (2005) finding that preprimary investment leads to higher returns to investments in education, with investment especially effective in the lives of disadvantaged children.

Turning to research and M\&E, our study revealed a significant neglect of both areas by foundations, due in large part to a lack of understanding about their value. Not only is this detrimental to the organisation itself in terms of being both efficient and effective, but also in terms of establishing the philanthropic sector as a knowledgeable, trustworthy and rigorous partner for educational development. For philanthropic organisations to truly have a long-term positive impact on education, they need to establish their credibility. Without proper $M \& E$ and published evaluations of programmes and initiatives, it is hard for governments and other organisations to know if foundations are worth partnering with. M\&E is also internally valuable, with the Grantmakers for Effective Organizations and the Council on Foundations (2009) finding that M\&E is useful as a vehicle for improving the likelihood of reaching goals, as a mechanism to better understand an issue, as a reinforcement of stakeholder engagement and as a tool with which to learn, even from failure. One of the foundations active in $\mathrm{M} \& \mathrm{E}$ in a non-GCC country explained that $\mathrm{M} \& \mathrm{E}$ is 'a new idea to a lot of people' and takes time to become common practice (Interview 9, 2018). However, without these mechanisms in place, organisations run the risk of not being trusted.

While M\&E has tangible benefits for the foundation itself, there is also a great need for philanthropic organisations to fund or conduct research, as there is a shortage of research on education in the region. At the time of this study, only 11 per cent of foundations working in education were conducting or supporting research and none of these were corporate foundations. Supporting research on education generates new opportunities to contribute knowledge and ultimately advances the education sector by grounding and adapting programmatic work to the local context. Increasing quality research on education in the MENA philanthropic sector would also help spread knowledge about Middle Eastern educational operations and philosophies to the rest of the world, while also possibly revealing new education models. With more research on education and the work of foundations in education, new foundations, as well as 
existing ones, would be more aware of underserved areas in the education sector and possible opportunities.

MENA philanthropic organisations currently stand at a crossroads at which they need to decide not only how long they want to be around, but also what kind of partner they want to be in the education sector. In order for the philanthropic sector to have greater impact in the region, it will be important for organisations to consider the issues raised above and how much, or how little, they wish to partner with other entities and national governments. Without a more robust and sustainable approach, however, the future or impact of regional philanthropy on the education sector is unclear.

\section{CONCLUSIONS AND FUTURE RESEARCH}

Going forward, future research about the sustainability of the philanthropic sector in the MENA region would be invaluable, especially relating to funding, in order to understand the extent to which organisations are financially independent. Additionally, more research on underserved populations, in particular pre-primary students, would contribute to supporting future directions for regional philanthropy. Research could also explore how education policy is designed and delivered in the region and the current role that philanthropy plays in this, alongside exploring future opportunities. Finally, more research is required to understand the different types of philanthropic institutions (state, business or family) in the GCC versus the non-GCC countries, with particular consideration of how this impacts operational priorities and regional politics.

The past two decades have seen increased involvement in the MENA education sector by both private and state-funded foundations (Srivastava \& Oh, 2010; Zunz, 2014). However, a lack of coordination, coupled with little research and little $M \& E$ appears to have resulted in a duplication of efforts, such as many foundations focusing on students and scholarships, while other areas have been neglected, such as research, early childhood education and support for educators. Through greater coordination and collaboration, alongside a more supportive regulatory framework, philanthropic actors in the region have a unique opportunity to provide support for those populations that are perhaps not high on domestic agendas or for areas where there is not enough public funding. Foundations are uniquely positioned to provide critical policy support, through research and advocacy, for government bodies that may not have the resources or time to be able to conduct such activities. However, if they lack rigorous M\&E and spend little to no time on research, then it is unlikely that governments will seek them out. 


\section{ACKNOWLEDGEMENTS}

The authors would like to express their sincere gratitude to the following philanthropic organisations for their willingness to share more about their work in education for this project: Abdulla Al Ghurair Foundation, Al Alfi Foundation, AlMabarrah AlKhalifia Foundation, A. M. Qattan Foundation, Arab Science and Technology Foundation, Emirates Literature Foundation, Help Center, Israel Science Foundation, Jusoor, King Khalid Foundation, Kuwait Foundation for the Advancement of Science, Oman LNG Development Foundation, Queen Rania Foundation, Sawiris Foundation for Social Development, SEKEM Development Foundation, and the Zayed bin Sultan Al Nahayan Charitable \& Humanitarian Foundation. We would also like to thank the three additional foundations working in education that participated but requested to remain anonymous.

Additionally, we would like to acknowledge and thank Hanadi Mohammad, Sahar ElAsad and Brian Jaewon Chung for their support contacting philanthropic organisations across the MENA region. We would also like to express our gratitude to David Dingus and Max Eckert for editing the chapter.

\section{REFERENCES}

Arnove, R. F. (Ed.). (1984). Philanthropy and cultural imperialism: The foundations at home and abroad. Bloomington, IN: Indiana University Press.

Association of Charitable Foundations. (n.d.). What is a foundation? Retrieved October 10, 2018, from http://www.acf.org.uk/about/what-is-a-foundation/

BBB Wise Giving Alliance. (2003). Standards for charity accountability. Retrieved November 20, 2018, from https://www.bbb.org/us/storage/0/Shared\%20Docu ments/Standards $\% 20$ for $\% 20$ Charity $\% 20$ Accountability.pdf

Berman, E. (1983). The Influence of the Carnegie, Ford, and Rockefeller Foundations on American foreign policy: The ideology of philanthropy. New York, NY: SUNY Press.

Brenner, D. (2012). Are Chinese NGOs 'going out'? The role of Chinese NGOs and GONGOs in Sino-African relations. Journal of Public \& International Affairs, 22, 131-152. Retrieved January 10, 2018, from http://jpia.princeton.edu/sites/ jpia/files/2012.pdf

Charter of the Gulf Cooperation Council (GCC). (1981, May 25). Retrieved November 10, 2018, from http://www.gcc-sg.org/en-us/AboutGCC/Pages/Primary law.aspx

Council on Foundations. (n.d.). Glossary of philanthropic terms. Retrieved November 15, 2018, from https://www.cof.org/content/glossary-philanthropic-terms

Cullinane, M. (2013, October 23). Nonprofit law basics: What is the difference between a public charity \& a private foundation? Retrieved November 20, 2018, from https://cullinanelaw.com/difference-between-public-charity-and-private-fo undation/ 
Cunha, F., \& Heckman, J. J. (2007). The technology of skill formation (IZA Discussion Papers, No. 2550). Bonn, Germany: Institute for the Study of Labor. Retrieved March 15, 2018, from http://hdl.handle.net/10419/34212

Eikenberry, A. M., \& Nickel, P. M. (2006). Towards a critical social theory of philanthropy in an era of governance. Manuscript submitted to Social, Political, Ethical, and Cultural Theory Research.

Eikenberry, A. M., \& Nickel, P. M. (2009). A critique of the discourse of marketized philanthropy. American Behavioral Scientist, 52(7), 974-989.

Farouky, N. (2016). The state of Arab philanthropy and the case for change. Development in Practice, 26(5), 637-645. https://doi.org/10.1080/09614524.2016. 1188888

Foundation Center. (n.d.). Grantspace: Knowledge base: What is the difference between a private foundation and a public charity? Retrieved January 10, 2018, from http://grantspace.org/tools/knowledge-base/funding-resources/foundations/ private-foundations-vs-public-charities

Grantmakers for Effective Organizations, \& the Council on Foundations. (2009). Evaluation in philanthropy: Perspectives from the field. Washington, DC: Grantmakers for Effective Organizations. Retrieved March 15, 2018, from https://www.hfcm.org/CMS/Images/Evaluation_in_Philanthropy_--_GEO_COF .pdf

Hager, M. A., Pollak, T., \& Rooney, P. (2001). Variations in overhead and fundraising efficiency measures: The influence of size, age, and subsector. Retrieved November 10, 2018, from https://archives.iupui.edu/bitstream/handle/2450/7754/ variations_in_overhead_and_fundraising_efficiency_measures.pdf?sequence $=1$

Hudson Institute. (2015). The index of philanthropic freedom. Washington, DC: Author. Retrieved January 10, 2018, from https://hudson.org/research/11259-theinteractive-map-of-philanthropic-freedom

Ibrahim, B. L. (2008). Arab philanthropy in transition. In B. L. Ibrahim \& D. H. Sherif (Eds.), From charity to social change: Trends in Arab philanthropy (pp. 1-21). Cairo, Egypt: The American University in Cairo Press.

Internal Revenue Service. (2017). Private foundations. Retrieved November 10, 2018, from https://www.irs.gov/charities-non-profits/charitable-organizations/pri vate-foundations

Johnson, P. D., \& Rahim, T. (2018). Great expectations: The growth of institutional philanthropy in the United Arab Emirates. Cambridge, MA: Belfer Center for Science and International Affairs, Harvard Kennedy School.

Khallaf, M. (2008). The State of Qatar. In B. L. Ibrahim \& D. H. Sherif (Eds.), From charity to social change: Trends in Arab philanthropy (pp.149-163). Cairo, Egypt: The American University in Cairo Press.

Knight, B., \& Ribeiro, P. (2017). A new global picture of organisations serving philanthropy: Growing and strengthening the field. São Paulo, Brazil: Worldwide Initiatives for Grantmaker Support. Retrieved May 15, 2018, from https://phi lanthropyinfocus.org/2017/03/16/philanthropy-infrastructure-at-a-glance-how-togrow-and-strengthen-the-field/

Marten, R., \& Witte, J. M. (2008). Transforming development? The role of philanthropic foundations in international development cooperation. Berlin, Germany: Global Public Policy Institute. Retrieved May 15, 2018, from http://www.gppi.net/ fileadmin/user_upload/media/pub/2008/marten-witte_2008_transforming-develo pment-philanthropic-foundations.pdf

Moeller, K. (2014). Searching for adolescent girls in Brazil: The transnational 
politics of poverty in 'The Girl Effect'. Feminist Studies, 40(3), 575-601. Retrieved November 10, 2018, from http://www.jstor.org/stable/10.15767/ feministstudies.40.3.575

Rice, J. K. (2003). Teacher quality: Understanding the effectiveness of teacher attributes. Washington, DC: Economic Policy Institute.

Ridge, N., \& Kippels, S. (2017). The rise and role of state philanthropy in the United Arab Emirates. In M. C. Thompson \& N. Quilliam (Eds.), Policy-making in the GCC: States, citizens and institutions (pp.271-298). London, England: I. B. Tauris \& Co. Ltd.

Sawiris Foundation. (2018). Training for employment projects. Retrieved January 25, 2018, from sawirisfoundation.org/projects-programs/training-for-employment/

Schütz, G., Ursprung, H. W., \& Woessmann, L. (2005). Education policy and equality of opportunity (IZA Discussion Papers, No. 1906). Bonn, Germany: Institute for the Study of Labor. Retrieved January 20, 2018, from https://www.econstor. eu/handle/10419/33448

Srivastava, P., \& Oh, S. A. (2010). Private foundations, philanthropy, and partnership in education and development: Mapping the terrain. International Journal of Educational Development, 30(5), 460-471.

Venngage Inc. (n.d.). Venngage [Website]. Retrieved November 15, 2018, from https://venngage.com/

Worldwide Initiatives for Grantmaker Support. (2018, January 30). The global landscape of philanthropy. São Paulo, Brazil. Retrieved November 20, 2018, from http://wings.issuelab.org/resource/the-global-landscape-of-philanthropy.html

Zunz, O. (2014). Philanthropy in America: A history. Concord, MA: Princeton University Press. 